\title{
Effect of Tween 80 on incubation period of Lactobacillus casei assay of serum folate
}

\author{
G. B. TENNANT \\ From the Department of Haematology, Welsh National School of Medicine, Heath Park, \\ Cardiff CF4 $4 X N$, UK
}

SUMmaRY Contamination of folic acid assay medium with oleate led to a lag phase when Lactobacillus casei cultures were grown on folic acid but not when whole serum provided the folate source. This led to high assay values when using 20 -hour incubation periods but satisfactory results were obtained after 48 hours' incubation. The addition of Tween 80 to the medium eliminated the lag phase and the assay results were consistent after 13,24 , and 48 hours' incubation.

The Lactobacillus casei response to folate is normally estimated by measuring the culture turbidity after 16 to 20 hours' incubation. Streeter and O'Neill (1969) found that cultures containing serum grew more rapidly than similar cultures containing folic acid (PteGlu) unless grown into the stationary phase (44 hours). Others, however, have reported comparable results from 20- and 44-hour assays (Slade et al., 1974; Tennant et al., 1974). Eichner and Dickson (1974) obtained similar results to Streeter and O'Neill (1969) when using BBL folic acid assay PGA broth but not with Difco's Bacto-folic acid casei medium. The overall pattern of results is similar to that expected if free fatty acids were present in the assay systems of some workers. Free fatty acids inhibit the growth of $L$. casei (Williams and Fieger, 1946) unless adsorbed by albumin (Williams and Fieger, 1949) or a suitable non-ionic detergent (Davis and Dubos, 1947; Williams et al., 1947).

\section{Material and methods}

L. casei subspp. rhamnosus (NCIB 10463) was grown as described previously (Tennant et al., 1974) except that the phosphate buffer concentration was reduced to $0.075 \mathrm{M}$. BBL folic acid assay PGA broth (Becton Dickinson (UK) Ltd) was used but Tween 80 was not added unless specifically stated.

Glassware was washed using Tetralab 3456 alkaline detergent (Savilles Hydrological Corporation Ltd) covered with aluminium caps or foil and sterilised at $165^{\circ} \mathrm{C}$. Some experimental tubes

Received for publication 15 August 1977 were boiled in water containing Lux soap flakes $1.25 \mathrm{~g} / 1$ and washing soda (sodium carbonate) $2.5 \mathrm{~g} / 1$ with minimal rinsing.

Potential sources of free fatty acids were examined for effects on the values obtained in the whole-serum folate assay. Results from 13- or 24-hour assays were compared with results from 48-hour assays and differences were tested for significance by the paired $t$ test.

Tween 80 was obtained from Fisher Scientific Co, New Jersey, USA (T-164); Hopkins and Williams Ltd, Chadwell Heath, Essex (885300); Koch Light Ltd, Colnbrook, Buckinghamshire (7773h). Serva was obtained from Micro-Bio Laboratories Ltd, London SW6 (37475) and Sigma (London) Ltd, Kingston upon Thames, Surrey (P1754). Three sources of casein hydrolysate were tested-BBL Acidcase No. 2 (low salt) $=2.5 \mathrm{~g} / 1$; Bacto-Casaminoacids (vitamin free) $=6.25 \mathrm{~g} / 1$; Bacto-Casitone (vitamin free) $=0.75 \mathrm{~g} / \mathrm{l}$. Non-absorbent cotton-wool (Robinson and Sons Ltd, Chesterfield, Derbyshire) was used to plug a $250-\mathrm{ml}$ conical flask which was sterilised in an oven at $165^{\circ} \mathrm{C}$ for one hour. After cooling, $180 \mathrm{ml}$ of assay medium was added. A similar volume of medium was autoclaved $\left(121^{\circ} \mathrm{C}\right.$ for 15 minutes) in a flask plugged with non-absorbent cotton-wool.

\section{Results}

\section{OLEATE INHIBITION}

In medium without Tween 80 cultures growing on PteGlu were 100 times more sensitive to oleate than when the folate source was serum (with similar folate concentrations) (Table). The addition of $2 \mathrm{~g} / \mathrm{l}$ 
Table Factors influencing oleate inhibition of a 20-hour whole-serum folate assay

\begin{tabular}{lll}
\hline $\begin{array}{l}\text { Folate source } \\
\text { and additions }\end{array}$ & \multicolumn{2}{c}{$\begin{array}{c}\text { Mean inhibitory oleate concentration* } \\
(\mu \mathrm{g} / l) \text { in medium containing: }\end{array}$} \\
\cline { 2 - 3 } & No Tween & $\begin{array}{l}2.5 \mathrm{ml} \text { Tween } \\
(1 / 10) / l\end{array}$ \\
\hline $\begin{array}{l}\text { PteGlu }(1 / 40 \times 5 \mu \mathrm{g} / \mathrm{l}) \\
\text { PteGlu }(1 / 40 \times 5 \mu \mathrm{g} / 1) \\
\quad+2 \mathrm{~g} \text { albumin } / 1\end{array}$ & 4.6 & 290 \\
$\begin{array}{c}\text { Serum pool }(10 \mathrm{sera}) \\
(1 / 40 \times 5 \mu \mathrm{g} / \mathrm{l})\end{array}$ & 155 & 515 \\
\hline
\end{tabular}

*Concentration of oleate which reduced growth to one-half of that in similar cultures which contained no oleate.

albumin (bovine plasma fraction V, Armour Pharmaceutical Ltd) increased the concentration of oleate that $L$. casei tolerated, but less effectively than serum. The addition to the medium of Tween 80 $(2.5 \mathrm{ml}$ of a $1 / 10$ solution/l) led to the growth response being unaffected by oleate at concentrations up to about $100 \mathrm{mg} / \mathrm{l}$.

Results from 20-hour assays were affected by oleate concentrations greater than $2 \mathrm{mg} / \mathrm{l}$ when there

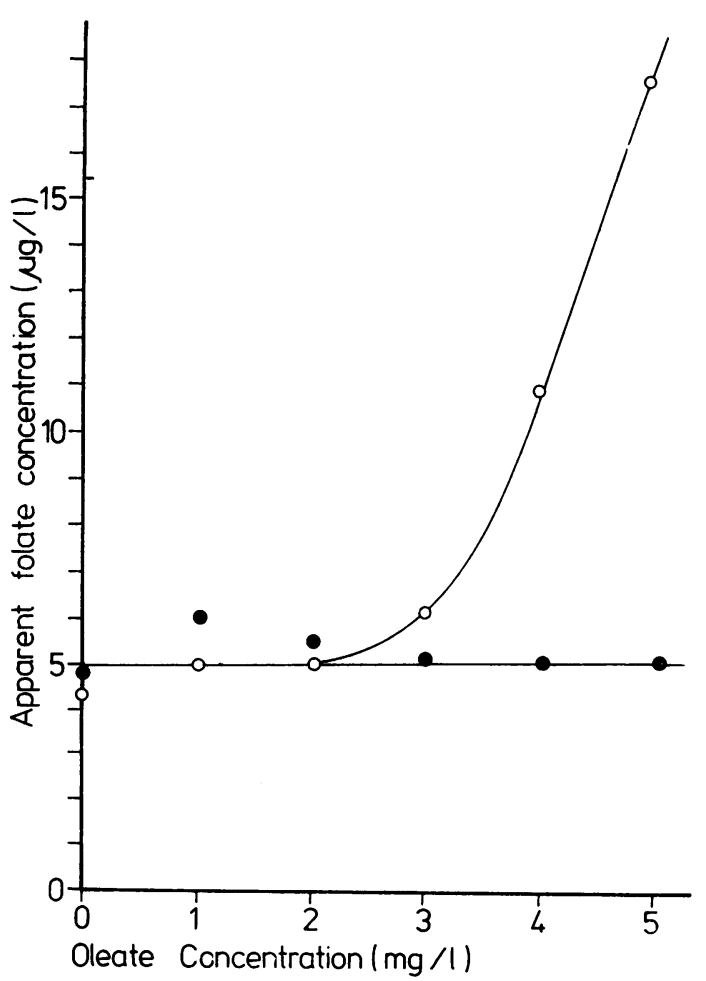

Fig. 1 Effect of medium oleate concentration on whole-serum folate assay results from cultures grown in medium without Tween 80 for 20.5 hours $(O)$ and for 48 hours $(\mathbf{O})$. was no Tween 80 in the medium. Assays became parallel if incubated for 48 hours (Fig. 1).

A study of culture growth showed that the presences of oleate led to a lag phase of several hours followe $\Phi$ by an exponential phase where the growth rate was? about twice that of cultures with no oleate or thoses containing serum (Fig. 2). The lag phase waß eliminated by adding Tween $80(2.5 \mathrm{ml}$ of $1 / 10$ solution/l) to the medium when oleate was added at low concentrations. At higher oleate concentrations the lag phase was merely shortened. The $L$. caset growth curves in the presence of other inhibitore? substances $(\mathrm{KCl}$, chloramphenicol, and ethanol\$ showed reductions in the rate of exponential growtliw but no lag phase when grown on PteGlu or seruna folate.

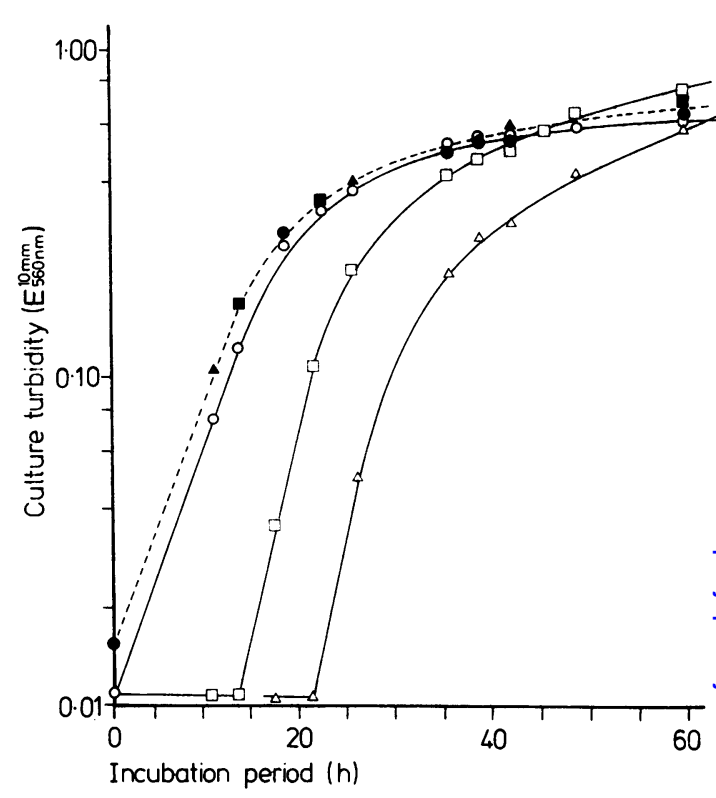

Fig. 2 Culture development of Lactobacillus casei (a) with PteGlu as folate source + Tween $80(\bigcirc)$, + Tween 80 and $400 \mathrm{mg}$ oleate $/ \mathrm{l}(\square)$, no Tween $+10 \mathrm{mg}$ oleate/l $(\triangle) ;(b)$ with pooled sera as folate source $(\Theta, \square, \triangle$ respectively).

\section{POSSIBLE SOURCES OF FREE FATTY ACIDS Tween 80}

When Tween 80 was added to the medium there wer no significant differences between the results from assays incubated for 13,24 , or 48 hours when the medium was autoclaved $\left(121^{\circ} \mathrm{C}\right.$ for 15 minutes or used without heating. When using autoclave $\$$ BBL medium without Tween 80 there was a smal but significant $(\mathrm{P}<0.05)$ increase in the mean folate values in the 13-hour assays. 


\section{Casein hydrolysates}

There was no evidence of contamination of the casein hydrolysates with free fatty acids or of their release during autoclaving.

\section{Glassware washing}

The addition of soap to the medium inhibited $L$. casei growth identically to potassium oleate (Table). However, the use of soap-washed tubes did not give uniformly higher results in 13- or 24-hour assays even after autoclaving 4-ml volumes of medium in the tubes. There was inhibition of growth in a few PteGlu standard cultures from each set of tubes. The degree of inhibition varied but was sufficient to affect some of the assay results significantly when using 13 -hour incubation periods.

\section{Glassware sterilisation}

Inhibitory concentrations of free fatty acids were not released from the non-absorbent cotton-wool used to plug glassware during sterilisation by hot-air oven or autoclaving.

\section{Discussion}

The results show the importance of adding Tween 80 to the medium of a whole-serum folate assay when there is any possibility of free fatty acids being present. Davis and Dubos (1947) noted that serum albumin removed the inhibitory effects of fatty acids in bacterial media. The growth responses of cultures growing on PteGlu and serum folate in the presence of oleate (Fig. 2) had characteristics similar to those described by Streeter and O'Neill (1969) in their assays. The pattern of erroneous serum folate assay results obtained when the assay medium contained oleate (without Tween 80 ) was also similar to that found by Streeter and O'Neill (1969). Tween 80 was effective in overcoming the consequences of oleate in the medium, allowing comparison of cultures containing PteGlu standards and serum samples after any convenient incubation period. The differences noted between BBL and Difco assay media (Eichner and Dickson, 1974) may be related to the addition of Tween 80 to the Difco medium at source. The instructions for the use of BBL medium direct that Tween 80 should be added by the user.

While free fatty acids can cause problems in the serum folate assay their potential sources remain speculative. There was no effect on the assay results from fatty acid contamination due to hydrolysis of Tween 80 (Davis and Dubos, 1947), casein hydrolysate (Demain et al., 1959), or distillation from non-absorbent cotton-wool (Wright, 1934;
Boyd and Casman, 1951; Girdwood, 1960; Hart et al., 1962).

The lag phase is probably caused by the incorporation of exogenous fatty acid into the cell membrane, as seen in L. plantarum (Holden and Bunch, 1972). Physical thickening of the membrane would disrupt the active transport mechanisms until the protein components had adjusted to the new thickness.

\section{References}

Boyd, D. M., and Casman, E. P. (1951). Inhibition of a strain of Brucella abortus by medium filtered through cotton. Public Health Reports, 66, 44-49.

Davis, B. D., and Dubos, R. J. (1947). The binding of fatty acids by serum albumin, a protective growth factor in bacteriological media. Journal of Experimental Medicine, 86, 215-228.

Demain, A. L., Hendlin, D., and Newkirk, J. A. (1959). Role of fatty acids in the growth stimulation of Sarcina species by vitamin-free casein digests. Journal of Bacteriology, 78, 839-843.

Eichner, E. R., and Dickson, V. L. (1974). Effect of incubation time on Lactobacillus casei bioassay. American Journal of Clinical Pathology, 62, 840-845.

Girdwood, R. H. (1960). Folic acid, its analogues and antagonists. Advances in Clinical Chemistry, 3, 235-297.

Hart, P. D., Lovelock, J. E., and Nash, T. (1962). The lethal effect of cotton-wool lipid on tubercle bacilli in acid conditions and its prevention by surface-active agents. Journal of Hygiene, 60, 509-525.

Holden, J. T., and Bunch, J. M. (1972). Stimulation by fatty acids of amino acid accumulation in pantothenic acid depleted Lactobacillus plantarum. Biochemical and Biophysical Research Communications, 46, 437-442.

Slade, B. A., Harrison, J. W., and Shaw, W. (1974). Effect of incubation time on folate values. American Journal of Clinical Pathology, 61, 74-77.

Streeter, A. M., and O'Neill, B. J. (1969). Effect of incubation time on the $L$. casei bioassay of folic acid in serum. Blood, 34, 216-221.

Tennant, G. B., Newberry, C. H., Davies, J., and Dziedzic, H. (1974). A comparison of seven strains of Lactobacillus casei var. rhamnosus in relation to their use in the microbiological assay of serum folate. Journal of Applied Bacteriology, 37, 373-389.

Williams, V. R., and Fieger, E. A. (1946). Oleic acid as a growth stimulant for Lactobacillus casei. Journal of Biological Chemistry, 166, 335-343.

Williams, V. R., and Fieger, E. A. (1949). Further studies on lipide stimulation of Lactobacillus casei. Journal of Biological Chemistry, 177, 739-744.

Williams, W. L., Broquist, H. P., and Snell, E. E. (1947). Oleic acid and related compounds as growth factors for lactic acid bacteria. Journal of Biological Chemistry, 170, 619-630.

Wright, H. D. (1934). A substance in cotton-wool inhibitory to the growth of the Pneumococcus. Journal of Pathology and Bacteriology, 38, 499-501. 